\title{
THE IMPACT OF THE ECONOMIC CRISIS IN THE IT\&C INDUSTRY - EVIDENCE FROM BUCHAREST
}

\author{
Claudia POPESCU ${ }^{1)}$ Alexandru GAVRIŞ ${ }^{2)}$ \\ 1) The Bucharest Academy of Economic Studies, Institute of Geography Romanian \\ Academy, Romania; ${ }^{2}$ The Bucharest Academy of Economic Studies, Romania
}

\begin{abstract}
Despite its peripheral location within the European metropolitan system, Bucharest has significant competitive advantages - large scale market, high-skilled labour pooling, dynamic business environment, institutional capacity, and knowledge organizations. The location of MNCs has enhanced the domestic small-scale entrepreneurship and the emergence of an innovative IT\&C cluster. As the world economic crises stroke almost everywhere, in the case of Bucharest it was enhanced by a political crisis which diminished the industrial growth. In this context we focus on the IT small and medium enterprises which, by surviving the crises and developing even more, show clear evidence of strengthening the cluster identity. Based on the two-digit CANE data on employment, the paper analyzes in an empirical way the IT firms from Bucharest between two representative moments: 2007 the year of maximum growth for Romania and 2010 . We attempt to identify the factors contributing to the growth of the cluster and to assess the contribution of the cluster to the generation of regional wealth and jobs. The results shows that, despite of the crises, the local entrepreneurship alongside the continuous foreign interest in the local workforce have pulled together an emerging industrial cluster.
\end{abstract}

Key Words: IT industry, entrepreneurship, economic crisis, Bucharest.

\section{Introduction}

New economic geographers argue that increasing returns and externalities are not international or even national in scope, but arise through a process of regional economic agglomerations (Malecki 1981, Markusen et al. 1986, Storper 1986).The agglomerating forces are basically localization and urbanization externalities which tend to lead to the local clustering of economic activity. The symbiotic relations between industrialization and metropolitan growth are extensively documented at the global level (Chakravorty et al. 2003, Davellar and Nijkamp 1989). Industrial success in big cities is a cumulative causation process where increasing returns are derived from industrial clustering. Economic growth is ever more based upon the effective utilization of intangible assets such as knowledge, skills and innovative potential as the key resource for competitive advantage (Roman 2010). The accumulation of knowledge and its spillover into productive capacity through technological change is a central theme of scientific inquiry in regional sciences. Subsequently, a large number of empirical studies have focused on the creation of knowledge, on R\&D activities, and on technological innovation as triggers of growing regional economies (Dosi 1988, Frenkel 2001). Knowledge-based economy and "Intelligent Cities" are closely related and stay at the core of the most dynamic regional economies.

Bucharest is an interesting case study due to its quick transformation from an industrial based 
economy towards a service based economy (Cees-Jan and Hoogerbrugge 2011). The shift from the communist period, led-by a dominant public sector, towards market-led private developments, has a strong impact on Bucharest urban economy. As a result, Bucharest has recently enjoyed a period of strong economic growth, turning into an innovative city of Central and Eastern Europe.

The paper begins by analysing the shift from manufacturing to services of the metropolitan economy. Deindustrialisation caused major economic and social dislocation with deep consequences on the labour market, sectoral structure and economic specialisation of the city. The radical evolutionary transformations engendered by the transition period were marked by strong social polarisation and regional divergence. Bucharest and some other regional cities have been able to survive the long-run decline since the early 1990s and have taken a different path of urban revival. The gaps between Bucharest and the rest of the country are typical for any national urban network dominated by a primate city. European integration it is thought to act as a powerful push for the enhancement of economic specialisation of the regions. Generally speaking, Romania is attractive for foreign investments because of the low-cost labour, but it seems that recently this advantage has been largely eroded. The second advantage and, apparently long-lived, is related to the pool of skilled labour in high-tech industries. The largest concentration belongs to Bucharest urban economy, therefore the next section of the paper is devoted to the analysis of the IT\&C cluster. Next, the results are presented and the factors contributing to the growth of the Bucharest IT clusters are discussed. Some discussion on the IT cluster in time of crisis and conclusions resume the paper.

\section{Bucharest after deindustrialisation}

All along the second half of the $20^{\text {th }}$ century, centrally planned industrialization characterized urban development in Romania. The socialist ideology had a strong urban bias and urbanization was considered to have a value per se (Ronnas 1982). Secondary activities and, especially heavy manufacturing industry, were given priority over primary as well as tertiary activities. Sectoral planning dominated over regional planning and, consequently, urban centres became places of concentration of manufacturing activities. As industrialisation has been deeply interwoven in the urban fabric during the socialist period, the highly industrialised regions of the country stood for the highly urbanised as well. Thus, before 1990, Bucharest was the most industrialized city of Romania, a symbol for the communist Romania. In early 1990s, 417 thousand persons were employed in manufacturing, representing $12.64 \%$ of the national industrial workforce and more than one third of the total employment at the metropolitan level. As world-widely noticed, industrial cities were at the epicenter of deindustrialisation which had far-reaching consequences determining the redefinition of the urban economies (Doussard et al. 2009). The deindustrialization as part of the economic restructuring was stronger and faster in Bucharest than in the rest of the country and continues to the day.

The metropolitan economy has been subject of a strong tertiarization process, the shift from manufacturing to services played a distinctive role in determining the spatial deconcentration of the Romanian industry. The contribution of Bucharest to the total laborforce in manufacturing went down from $12.64 \%$ in 1992 to $8.56 \%$ in 2008 . Given the high level of industrialisation at the beginning of the 1990s, the drop of industrial laborforce has had a direct influence on the total employment mainly engaged in industry-related sectors, from research and development to transportation, distribution, storage, wholesale and retail activities. Only few regions based on large urbanisation economies (Cluj, Brașov, Prahova, Timiș and the capital city) could pursue a strong tertiarization shift and balance their employment structures. All the rest have suffered dramatic losses of employment due to deindustrialisation combined with increasing 
self-employment in agriculture and slow growth rate of services. The loss of manufacturing employment in Bucharest has been higher than the national average all along the transition period scoring $60.63 \%$ in comparison with $50.14 \%$ at the national level. Markers of the socialist industry in Bucharest (Vulcan, Apaca, IMGB, 23 August, Republica, Electronica, Automatica, Steaua Rosie, Timpuri Noi, Uzinele Chimice Române) have closed down major facilities and initiated a new cycle of economic transformation. The long run decline of industry has been paralleled with the slowing revival of the services. The two sectors have been bound together in the same path of evolutionary transition with implications for the socio-economic sustainability of the metropolitan economy. Similarly the distribution of jobs and incomes has reconfigured the labor market of the city.

There have been two major consequences. On one side, the unemployment rate was constantly under check and scored the lowest value at the national level $(1.6 \%$ in 2008 and $2.3 \%$ in 2010). On the other side, media, legal and business services and high-tech industries flourished and provided a striking contrast with the general trend. The gains for the metropolitan economy were twofold: mutually reinforcing diversification and increasing wealth for people and the city. The dismantling of the urban industry has produced a significant labor input on the local market. As a result, basic services, especially retail activities, found fertile ground to prosper. The urbanization and agglomeration economies turned into drivers for growth and deindustrialisation in Bucharest has been accompanied by lower unemployment rate and growing regional GDP, FDI stock and net earnings. The favorable economic environment has resulted in increasing number of companies and labor force. The total employment has increased by $18.96 \%$ in Bucharest during the 1992 to 2008 period, whereas at the national level the trend has been reversed (a decrease of $16.36 \%$ ). Gradually, Bucharest has become the major attraction for FDI and MNCs location and domestic entrepreneurship is a result of successive spin-offs and spillovers. Bucharest is the richest region at the national level and all along the transition process the regional inequalities have widened. The ratio between the GDP per capita in the richest and the poorest region (Bucharest-Ilfov vs. NorthEast) has gone up from 1.96 in 1994 to 3.93 in 2008.

\section{"One country, two economies"}

Bucharest is a primate city; the ratio between Bucharest and the second-ranked city of the urban system is 1:7. Bucharest makes no exception from the "new economy" model with its upgrading of jobs and wages led by the high-tech sectors which is to be found in big cities (Doussard et al. 2009). Today the urban economy of Bucharest is mainly based on services $(70 \%)$, industry $(20 \%)$ and construction $(10 \%)$. The tertiary sector is important with a high percentage of advanced ICT, telecommunication, services, but also the banking sector (finance).

The economy is strongly driven by foreign direct investments. The National Bank of Romania (BNR) stated that FDI is unevenly distributed in Romania. According to BNR data for the years 2003-2006, the region of Bucharest-Ilfov recorded over 60 percent of total FDI, with the other seven development regions in Romania sharing the rest. Of all East European countries, Bucharest is in the top three of highest FDI after Moscow and Prague (Chilian 2009, Roman 2010). Many foreign companies invest in Bucharest because of a host of reasons. Strength of Bucharest economy is related to its gateway function within Central-and Eastern Europe. Logistics and transport activities are an important part of the service-profile of Bucharest. It has a high investment potential. The metropolitan economy, the large scale market and the diversity of skills play a major role in attracting various investments. Bucharest attracted many foreign companies with its low costs, largely explaining high percentage of FDI. More recently, 
Romania's low-cost advantage is gradually eroded in certain sectors, facing increasing competition from Asian economies in clothing and leather, and, recently, in IT industries. The labor force cost has increased by $11 \%$ during 2000 and 2005 and recorded the highest raise in 2007 as compared with all the other EU members (Competitiveness Report Romania 2007, UniCredit Group, March 2007). The metropolitan economy is based on dynamic SMEs. In 2005 the number of SMEs per 1,000 inhabitants scored 51.9, two times higher than in NW, W, SE, and Centre and even three times higher than in SW, S and NE regions. Bucharest-Ilfov takes lead in some other ways: high contribution to total profitable SMEs (22.6\%); high specific weight in turnover total volume of the sector (50.4\%); a profit volume per company more than 2 times higher the national average and 4 times higher than the NE region (Isaic-Maniu, 2008).

Bucharest has a significant contribution to the territorial polarization of economic growth. The economic recession had minor drawbacks on the metropolitan economy. In 2009 the highest employment rate was $62.8 \%$ in Bucharest-Ilfov region (Dachin and Popa 2011). Bucharest labor market is characterized by the majority of the employees having a university degree, wages relatively low, and the attractive working ethos for companies. In this region about $20 \%$ of the population aged 15-64 years represents employed persons with tertiary education and only $5 \%$ with low education. In the 2000s, more exactly between 2003 and 2009, the share of employment in the total working age population has grown in Bucharest by $6.8 \%$ whereas at the national level the trend was quite the opposite. Illustrative in this respect is that by levels of education the employment in Bucharest took followed a distinctive way: strong increase of the highly educated people $(+6.1 \%)$ and slow decrease for the low educated people $(-1.1 \%)$. The gap in economic performance between Bucharest-llfov region and all the other regions is significant and has increased in the 2000s. The capital city is the main attraction for young and educated labor force searching for higher income. One explanation is that the capital city concentrates a high share of services, including services within the central administration which demands for high qualification (Dachin and Popa 2011). Another explanation is that BucharestIlfov is highly atypical region mostly due to the exporter's location bias (main foreign and domestic companies headquarters), high export share in many product sections and groups, and high specialization index (Chilian 2009).

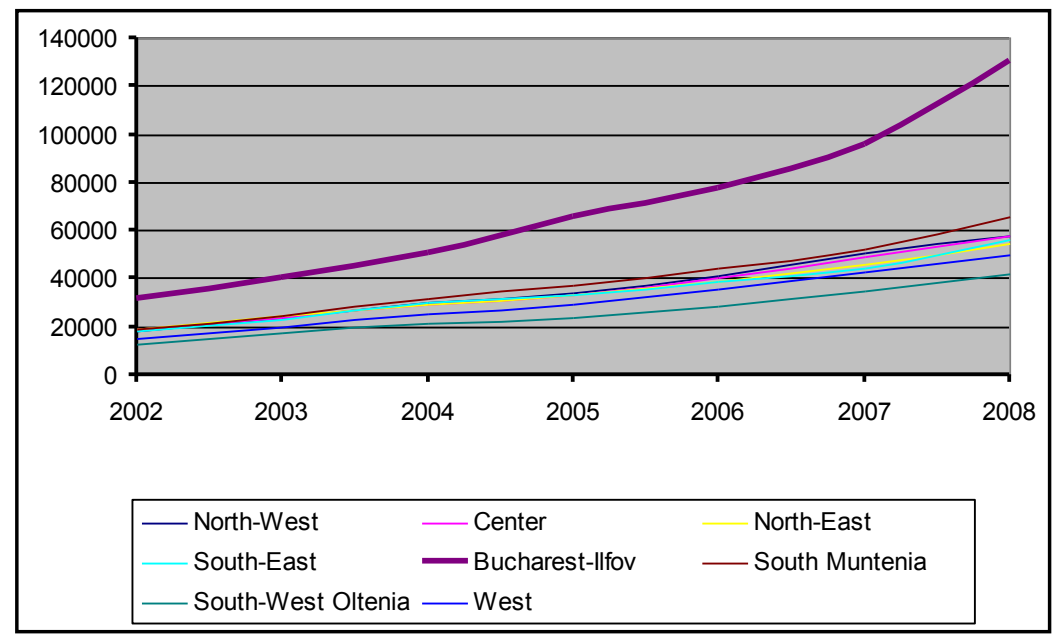

Fig. 1 - Regional GDP (LEI million current prices)

Source of data: Statistical Yearbook 2009, INS 


\section{IT\&C Industry}

At the level of the global economy, the IT\&C sector is one of the most important engines of growth. Potentially, it is expected to play a similar role in the Romanian economy: Romania is one of the strongest markets in Europe for technology investment and trade, with a highly skilled technology workforce, competitive costs, top-tier investors and a friendly business environment (ARIS Sector Overview: IT 2008). The Romanian IT market is the second largest in CEE, following Poland. Before the onset of the economic recession in the last quarter of 2008, Romania had the fastest growing IT market in Europe (the growth rate varied between $20.2 \%$ in 2004 to $13.1 \%$ in 2006) according to EITO (European Information Technology Observatory 2007).

Romanian companies provide a significant contribution to IT outsourcing, business process outsourcing, call center support and product development at the global level. Prior to 2008, the estimations showed a number of over 13,000 IT companies in Romania. The IT sector comprises more than 3,000 technology companies and EUR 400 million in software and IT services revenue each year. About 9,000 companies are IT exporters with a significant growth potential and prospects to reach over one billion EUR in the next 2-3 years. The highly skilled labor pooling is one of the most important comparative advantages of Romania: it stands for the European leader and the $6^{\text {th }}$ in the world by the number of certified IT specialists supplied on the market by 5 polytechnic universities, 59 other universities, and 174 private colleges with technical degree programs. In average, 230 IT specialists/million people graduate every year, one of the highest rates in the world and greater than that of the USA and Russia (ARIS, Sector Overview: IT 2008). Traditionally, Romania has exceptional results at international informatics contests, placed in the top 4 with China, USA and Russia at the latest olympiads.

Besides the abundant and skilled workforce, there are some other strengths of the business environment that help the IT industry to expand: tradition in IT (one of the first European countries producing computers), $16 \%$ flat tax on profit, specific incentives (100\% income tax exemption for IT specialists in force since 2001), possibility of using the accelerate depreciation for the equipments (50\% in the first year), carry forward the fiscal losses for a period up to 5 years, subsidies for hiring and training fresh high school/university graduates, wide availability of language skills. All in all, the IT MNCs found a very fertile ground to develop their activities in Romania. Examples of Siemens, Freescale, Accenture, Ericson, Genpact, Alcatel have developed successful story of locating around the country A number of six MNCs preferred Bucharest as their main location. Intel Capital invested US\$12 million in Romanian IT services and outsourcing company, Siveco, in Bucharest. Infineon employs 250 R\&D engineers working on semiconductor design in conjunction with Polytechnic University of Bucharest. Oracle employs 100 engineers to develop compilers and development tools. For others, Bucharest is a perfect location to serve the regional or the global market: HP set up a BPO for financial and administrative services, dedicated to EMEA region, and looking at expansion up to 1,200 employees in few years; Microsoft decided in 2006 to set up a Global Technical Support Center with 700 employees; and WIPRO opened a BPO center for IT services covering the East European market with 700 employees.

After the onset of the economic crisis, Business Monitor International forecasted that the Romanian IT spending would record low-single-digit growth in 2010, following a sharp contraction in 2009 and double-digit declines in PC shipments. In 2010, consumer and business IT spending remained constrained by continued de-leveraging and rising unemployment, keeping spending growth below pre-2008 levels. In 2009, the Romanian 
government looked to EU structural funds to prevent stagnation in the domestic IT market and stimulate investment. Information and communication technology projects worth EUR125 million had been approved for financing and a total of EUR383 million had been earmarked for Romanian IT\&C sector for the 2007-2013 period. Slowly growing would be the computer hardware market. In 2009, there was a sharp contraction of demand and few vendors expected pre-2008 sales levels to be recorded in the near future. Anyway, the low level of computer penetration represents an opportunity for sales increase. Recent statistics suggested than $43.5 \%$ of urban dwellers owned a computer, while the nationwide figure for home computer ownership was just $24.6 \%$. Likewise, the software market suffered a decline in 2009 and a slow recovery one year later. Investments by businesses and the public sector are expected to grow by 2014 . The enterprise resource planning market is still in its infancy, where larger companies and organizations still provide strong demand. In other CEE states the focus of opportunity has shifted more towards SMEs sector. However, demand has gradually become more sophisticated, with increasing interest in support and technical assistance. The IT services market has passed through a similar path. Spending on IT services contracted in 2009 as enterprises cancelled or postponed IT projects as a result of the economic downturn. In 2010 IT services spending increased slightly driven by an inflow of EU funds and foreign investment. Additionally, the demand for basic enterprise software and hardware systems is far from saturated and continues to be an underlying driver for the services market.

\section{Bucharest IT Cluster: Factors, Data and Methods}

The main opportunity for Bucharest is to make a shift from a service-based economy towards a more knowledge-based economy. Various studies (Scott 1982, Feldman 1994, Anselin et al., 1997) have provided evidence of the advantages of the ability of metropolitan areas to attract hi-tech industries, which employ advanced technology and are strongly involved in the process of innovation. In comparison with the national average (0.31), Bucharest scores a value more than double of the Competitive Potential Index (0.68) recording the highest export values and the largest employed population (Cojanu et al. 2010). With a volume of almost two times higher than the second-ranked county, Bucharest is placed on the top position with a $18.1 \%$ share of total exports of Romania. In the same time, Bucharest is the main provider of high technology exports in sharp contradiction with the national economy (Table 1). This performance is, at least partially, due to the highly centralized pattern of research in Romania: over $50 \%$ of researchers and of the funds directed to this field being still concentrated in the capital, namely the region Bucharest-Ilfov. A recent assessment of research efficiency in Romania and Bulgaria found that only Bucharest-llfov region and other two Bulgarian regions score a high value. The analysis used inputs (R\&D expenditures, number of researchers, and employment in high and medium-skilled labor) and outputs (number of patents) for 2003-2005 (Roman 2010).

Technological Level of Exports (\%), 2009

\begin{tabular}{|l|r|r|r|}
\hline & High technology & Medium technology & Low technology \\
\hline Romania & 1.51 & 68.16 & 30.32 \\
\hline Bucharest & 18.02 & 39.19 & 16.16 \\
\hline
\end{tabular}

Source of data: Centrul Român pentru Promovarea Comerțului şi Investițiilor Străine, 2010

During the last few years, there has been a decrease in the number of researchers and an increase of their average age. The main issue facing the field is the low level of financial backing from public funds. In Romania, research and development expenses totalled 653 
million EUR in 2007 and its percentage of the GDP was of $0.53 \%$, slightly increased compared to $0.45 \%$ in 2006 , but still among the lowest levels in the EU (idem). Basically, the field is confronted with the outdated R\&D infrastructure and failure to adjust to competitive market conditions. Another major problem consists of the still weak link between research and economy and the relatively scarce capability of putting the research results to good use. In Romania, at the level of 2007, the personnel in R\&D comprised around 33,000 employees, the equivalent to $0.6 \%$ of the total number of employees, one of the lowest percentages in the EU. According to World Bank's Knowledge Assessment Methodology (KAM), Romania was in 2009 on the 47 th position out of 145 countries.

The concentration of IT\&C industries in Bucharest is easily to be explained. The first reason is related to the location choices hi-tech industries make, which are considerably different from those made by traditional industries. Usually, after the initial product development and innovation, IT\&C firms locate close to centres of research and science and to places where they have a good chance of rapid market penetration. Therefore, the metropolitan area of Bucharest is a perfect location acting as an incubator for the emergence of technological change and, subsequently, of innovative firms. Connectivity and accessibility are major incentives for the co-location of high-tech firms in Bucharest. The Bucharest metropolitan area offers a well-developed, physical infrastructure and therefore it is expected that hi-tech firms will be attracted to locate there. Moreover, due to the slow urban regeneration there are important reserves of land in inner city locations and good prospects for further redevelopments. Skilled labor is of great importance, especially for the development of technical innovations. It is attracted to places with a high quality of life and cultural and educational activities that are more to be found in the large metropolitan areas. Universities play a central role, not only as producers of basic research, but also by creating human capital in the form of higher skilled labor. The importance of basic university research in the stimulation of technological innovation and higher productivity is derived from the public nature of the research, and the resulting positive externalities to the private sector in the form of knowledge spillovers. Both the knowledge spillovers and the human capital development constitute important location factors for private sector R\&D and for high technology production. Bucharest universities fuel the IT companies with highly skilled multilingual workforce accounting for $26.8 \%$ of the total number of graduates in IT and $42.2 \%$ of graduates in electronics in the academic year 2009-2010. The spatial concentration of institutions of higher education, technological research facilities and centers of knowledge in metropolitan areas increases information accessibility. As the cluster is consolidating, spin-offs and spillovers usually occur enhancing the innovative capacity. The agglomeration of firms provides a pool of technical knowledge and specialization, which will later develop new technologies.

Concentrations of business services create the marketing and commercial knowledge necessary for introducing innovation into the market. Their existence reduces the risk level and the cost related to the innovation process by providing important information on regulation, standardisation, marketing, product testing and financial knowledge. Business milieu is another factor explaining the location of IT firms in Bucharest. Entrepreneurship, in general, is more active in metropolitan environments. This is obviously the case of Bucharest where the number of SMEs/1,000 inhabitants is more than double in comparison with the national average (51.9 in Bucharest as against 24.8 at the national level). Entrepreneurship in IT\&C is even more visible, the number of companies has grown from 1959 in 2002 to 5206 in 2008 (Fig. 2). Software consultancy and software editing firms have contributed the most to this growth. The economic significance of Computer Software lies both in its role as a primary engine of national economic growth and in its importance in advancing technology-based regional and local economic development. The majority of these firms are small and independent, being closely 
linked to local markets of high skill and high wage labor. As a result, they have a special significance in stimulating local income growth and retaining scientific talent in various communities, a prerequisite for further innovation and economic growth. The recent explosion of IT\&C companies may be well explained by their small requirements for start up capital, space, and special infrastructure, and their limited, if any, environmental impact. In the same time, the growing number of IT\&C companies shows that the clustering process is firmly on track.

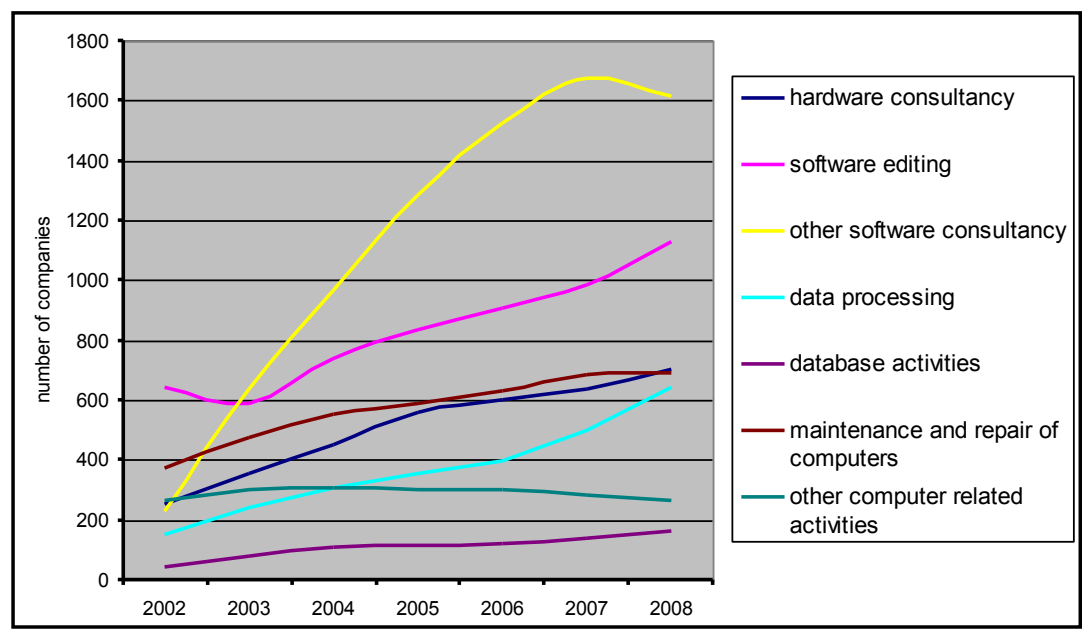

Fig. 2 - Entrepreneurship in IT\&C Industry in Bucharest

Source of data: Tempo on line, INS.

These firms enjoy two types of localization advantages. The first involves Marshallian factor externalities, namely pecuniary benefits in the form of lower average production costs stemming from the spatial concentration of labor (risk pooling) and the spatial clustering of input suppliers (scale economies in the provision/sharing of specialized inputs). Given the scale and quality of human capital in Bucharest, firms enjoy access to large specialized worker pools that reduces search costs for adequate employment. In such an environment, IT employment may be better insured against negative company-specific "shocks", as it can search for another job within the cluster at relatively low re-employment costs. The second involves technological spillovers, that is, non pecuniary advantages, where ideas and innovations circulate from one firm to the others, mutually enhancing their productivity. Besides transportation and transaction cost reductions, these firms are more likely to develop further business relationships and to foster a finer division of labor. For Computer Software firms clustering is economically rationale as they depend largely on non-standardized service inputs such as product design and packaging. Producers of such inputs may be subject to internal scale economies, and linkages to these producers may have geographically sensitive transactions costs. Transfer of knowledge is stimulated through both formal (subcontracts, technology agreements) and informal channels (employment inter-firm mobility, inter-firm interactions, or information exchange encouraged by tacit vertical integration). More over, IT firms are vulnerable to externality effects due to their weak capacity to monopolize knowledge and innovations they create and the strong ability of other firms to imitate.

Industrial cluster identification is dependent on the theoretical framework to which various studies are related to (vom Hofe and Chen 2006). The adopted solutions are based on the 
different methodologies as: interindustry linkages, graph-theoretic analysis, statistical cluster analysis and discriminant analysis, PCA and Porters' model - Diamond of Advantage. Other alternatives focus on the measurement approach. Some of the most used solutions of computing the geographic concentration of an industry are: Herfindahl index ( $\mathrm{H}$-index), location quotient, growth-share matrix, EG index etc. (Wang and Lin 2008).

The paper follows two directions for the analysis of ITC cluster from Bucharest. The first consists in the statistical validation of a cluster in the named sector, while the second focused on the evolution comparison between two key moments, the years 2007 and 2010. The importance of this period was marked by the profound changes developed as the world economic crisis spread to Romania and by the political instability from the respective years. The methodological result is a concurrent combination of the stages that allowed to prove the existence of a cluster and its viability in Bucharest city. As there is some reluctance (Wolfe and Gertler 2004) on the quantitative methods for cluster identification, the study is supported by additional research that emphasized the clustering of the IT industry in Bucharest. The insight on the cluster identity is supplemented by the authors previous studies on cluster formation, industrial location in Romania and by the studies on Bucharest.

The empirical analysis was the first stage where the solution of cluster identification proposed in the case of Sweden (Karlsson et al. 2003) was adopted. It was enhanced with the location quotient analysis to support the statistical evidence. Then, conditioned by the available data, we focused on the sector dynamic through a simple analysis on the evolution of firms and their characteristics. This guided the analysis to a general image and identification of some factors that were formed in the crisis period allowing the cluster survival. The study of Bucharest's IT cluster follows the above mentioned solution (Karlsson et al. 2003), but it is directed only towards the identification and not on regional evolution and characteristics. From this point of view the stages are:

- number of firms and employees that dominate in relation to regional size;

- regression estimation from the two equations, in which the residual results from Romania's county are kept and then used in the next stage.

$$
\begin{aligned}
& \ln E m p_{r}^{i}=a_{1}+b_{1} \ln P o p_{r}+\varepsilon_{1} \\
& l n P l a_{r}^{i}=a_{2}+b_{2} \operatorname{lnPla} a_{r}+\varepsilon_{2}
\end{aligned}
$$

Emp - employment in sector $\mathrm{i}$ of region $r$

Pop - population of region $r$

$\mathrm{Pla}-$ number of firms belonging to region $\mathrm{r}$ and sector $\mathrm{i}$

$\varepsilon$ - error term

- the subjective interpretation of the limit. A positive threshold over $10 \%$ from the residual results of the previous equations is considered as being enough for a cluster presence.

Furthermore, location quotient creates the basis for discussing the specialization of the IT industry in the city of Bucharest or the IT relative concentration. The computing equation follows the classical setup (Florence 1939):

$$
L Q=\frac{e_{i} / e}{E_{i} / E}
$$

$\mathrm{e}_{\mathrm{i}}=$ Local employment in industry $\mathrm{i}$

$\mathrm{e}=$ Total local employment

$\mathrm{E}_{\mathrm{i}}=$ Reference area employment in industry $\mathrm{i}$ 
$\mathrm{E}=$ Total reference area employment

Exploratory evaluation is the characteristic for the second phase of the study. Differences of the IT sector is drawn upon the primary variables of the firms. For comparison it was used the firms size, profits and their turnovers.

\section{Results}

The identification of IT cluster in Bucharest based on the two methods of assessment shows that in both situations the threshold of $10 \%$ is crossed-over. Obviously, the city as an administrative entity, is strongly differentiated from the rest of the regions, despite the economic crisis through which it keeps on passing. The regression analysis makes clear that the variables concerning the number of firms, and number of employees are consistent with the viability of the model, showing a slight change between the two years considered (Table 2). The figures show that the IT\&C sector in Romania has encountered only minor changes and the tendency of evolution is normal. Within the IT\&C industry, the 6201 and 6202 CANE divisions dominate, namely the client-oriented software and consultancy in information technology, and it would have been highly unexpected that during the recession period major structural changes would occur. As the analysis is focused on Bucharest, the regional context is not relevant.

Table 2

The relations between employment / number of firms in the IT sector and the population

\begin{tabular}{|l|r|r|l|l|r|}
\hline Firms & \multicolumn{1}{|l|}{2007} & $\mathbf{2 0 1 0}$ & Employees & \multicolumn{1}{l|}{2007} & \multicolumn{1}{l}{2010} \\
\hline Constant (t-value) & -7.277 & -7.379 & Constant (t-value) & -7.466 & -7.438 \\
\hline R2 adjusted & 0.74 & 0.75 & R2 adjusted & 0.72 & 0.73 \\
\hline No of observations & 42 & 42 & No of observations & 42 & 42 \\
\hline
\end{tabular}

The Location Quotient is calculated at the national level and the regional level of BucharestIlfov region as well. In the former case, the values are $\mathbf{1 . 9 1 3 8 7}$ for 2007, and $\mathbf{1 . 8 1 8 7 1}$ for 2010 . At the regional level, the figures are 1.07 in 2007 and 1.04 in 2010, respectively. The values indicate a relative stability of the spatial concentration pattern with a slight tendency of decline. Surely, the methodology of LQ analysis shows the clustering of IT industry in Bucharest. According to export base theory, Bucharest is a net supplier of IT products and services, although the scale of activities remains largely unknown.

The presence of the IT cluster in Bucharest is statistically tested, therefore the study applies the second methodological tool. In order to assess the changes between 2007 and 2010, the analysis is based on secondary data supplied by Borg Design data basis, which contains 594,424 firms located in Romania in December 2011. The primary interrogation resulted in a number of IT firms (CANE 62, 63 divisions) of 11,233, of which $41.25 \%$ are located in Bucharest. A relatively small share, of $11 \%$, are FDI meaning that entrepreneurship is the major driver of IT industry growth. Due to incomplete statistics, the analysis is focused on firms described by the whole set of data, referring to the number of employees, the net profit and turnover. Firms of the Communication sector have been subject of the statistical analysis. Additionally, the size factor was used to filter the IT firms, identifying the group of SMEs with less than 500 employees. So, SMEs in IT sector totalizes 2,261 firms in 2007 and 2,602 in 2010 , of which FDI companies account for $13 \%$ of the total in both years. 
Firstly, it is worth mentioning the sector dynamics. The number of firms has slightly increased, whereas the share of FDI remained constant. So, the cluster seems to be very robust and the dependence on foreign capital inflow less marked. Even during the harsh time of recession, the number of firms has grown. The same tendency was registered by the number of employees from 13,769 persons in 2007 the number was 5.1\% higher in 2010. Many other manufacturing sectors have been severely hit by the ongoing economic crisis, especially labour intensive and resource-based industries. In contrast, the IT sector registered a slowdown of growth and the stability of FDI. Secondly, the IT firms show a high level of performance and competitiveness as their turnover has increased by $11.8 \%$ between 2007 and 2010 .

During the economic crisis, a number of 1,750 have survived through reorganisations and adjustments. Table 3 shows that the SMEs of 2007 have grown in terms of employee's number with the exception of very small firms having less than 10 employees.

Number of firms and employees of SMEs in the IT sector

Table 3

\begin{tabular}{|c|r|r|r|r|r|}
\hline \multicolumn{1}{|c|}{ Employees } & \multicolumn{1}{c|}{$\mathbf{1 0}$} & $\mathbf{1 0 - 2 4}$ & $\mathbf{2 5 - 4 9}$ & $\mathbf{5 0 - 9 9}$ & $\mathbf{1 0 0 - 5 0 0}$ \\
\hline No. of firms 2007 & 1508 & 133 & 56 & 30 & 23 \\
\hline No. of firms 2010 & 1484 & 147 & 62 & 27 & 30 \\
\hline Employees 2007 & 4528 & 3906 & 2217 & 5915 & 3304 \\
\hline Employees 2010 & 5175 & 4913 & 2348 & 7422 & 2083 \\
\hline
\end{tabular}

The economic crisis has negative consequences on IT firms profit (Table 4). The ratio profit/ number of firms, as well as the productivity rate, shows a strong sensitivity of firms by size. The profit decrease is more or less sensed by all categories of firms with the exception of mediumsized firms (50-99 employees) which strengthened their economic power. The same tendency is characteristic of the ratio profit/employees. In order to gain a better understanding of the way IT firms have passed through the economic crisis the turnover assessment was necessary to make the connection with the market demand and its characteristics. Turnover decrease is scored by firms having 25-49 employees, while all the other enjoy a sustainable growth. The most remarkable increase is that of firms with more than 100 employees. They even doubled their turnover, from approximately 14.4 million RON to almost 30 million.

Table 4

Economic characteristics of SMEs from the IT sector

\begin{tabular}{|l|r|r|r|r|r|}
\hline \multicolumn{5}{|l|}{ Profit/no. of firms } \\
\hline & $<10$ & $\mathbf{1 0 - 2 4}$ & $\mathbf{2 5 - 4 9}$ & $\mathbf{5 0 - 9 9}$ & $\mathbf{1 0 0 - 5 0 0}$ \\
\hline $\mathbf{2 0 0 7}$ & 43519 & 334718 & 807516 & 692987 & 2057151 \\
\hline $\mathbf{2 0 1 0}$ & 41898 & 314364 & 572848 & 1038951 & 1587374 \\
\hline \multicolumn{5}{|l|}{ Productivity (profit/employees) } \\
\hline $\mathbf{2 0 0 7}$ & 19625.1 & 23150 & 22778.9 & 11925.2 & 9429.43 \\
\hline $\mathbf{2 0 1 0}$ & 18395.6 & 21285.8 & 13798.2 & 14437.3 & 9415.03 \\
\hline
\end{tabular}

In three year span of time, the number of new jobs totalized 3,119 persons. In this period, as compared with the number of firms, the number of jobs is slightly bigger in 2010 . This growth is 
explained by the the increasing significance of the IT sector in the metropolitan economy (Table 5 ). The growing contribution to the regional wealth shows that, in contrast with other economic sectors, the IT industry turned even stronger that before the onset of the economic crisis. Additional arguments in this respect concern the turnover of newly created firms and of the total IT sector. Thus, a smaller number of firms in 2010 produced a bigger turnover than that registered in 2007, the year of maximum economic growth in Romania.

Table 5

The IT\&C cluster evolution, 2007-2010

\begin{tabular}{|l|r|r|r|r|}
\hline & \multicolumn{1}{|c|}{$\mathbf{2 0 0 7}$} & \multicolumn{1}{c|}{$\mathbf{2 0 0 8}$} & \multicolumn{1}{c|}{$\mathbf{2 0 0 9}$} & $\mathbf{2 0 1 0}$ \\
\hline No of new Jobs & 467 & 1533 & 761 & 358 \\
\hline $\begin{array}{l}\text { IT Turnover (/year) } \\
\text { (Lei) }\end{array}$ & $31,015,605$ & $189,449,216$ & $104,783,586$ & $36,276,168$ \\
\hline No of SMS & 240 & 303 & 185 & 136 \\
\hline $\begin{array}{l}\text { Total Turnover in the } \\
\text { IT (Lei) }\end{array}$ & $3,444,454,134$ & $4,172,475,971$ & $4,331,495,529$ & $4,223,508,415$ \\
\hline Regional wealth (Lei) & 0.9 & 4.54 & 2.41 & 0.86 \\
\hline New jobs/SMS & 1.95 & 5.06 & 4.11 & 2.63 \\
\hline $\begin{array}{l}\text { IT Turnover I } \\
\text { Bucharest Turnover }\end{array}$ & 2.25 & 2.14 & 2.35 & 3.09 \\
\hline
\end{tabular}

The cluster evolution is strongly conditioned by the effects of the crisis. Nevertheless, there are statistical elements that show the positive dynamics of the cluster. The factors and impact of IT cluster on the economic environment are discussed in the next section of the analysis.

The effects of the firms from the Bucharest's IT cluster are hard to asses. Their impact to the regional wealth was developing at accelerate pace, but the crisis diminished the momentum. Even the data available pays a big role for a correct assessment. Even so, one may see the value of the SMS firms in times of crises. Entrepreneurship continued and the number of new firms remained relatively constant. The local initiative can be a generator for long time regional wealth. But even more important, the firms from this sector were powerful enough to employ new workers, when everyone was considering jobs cuts. Major effects are expected in the next decade or so. The reason is due to the overwhelming ratio of SME firms focused on services, rather than innovation or knowledge. Nevertheless, the sustainability of the IT sector is easily noticed; just that is at its very beginning.

\section{Discussions}

In Romania, the period of transition that followed the turning point at the end of the 1980s, has been marked by successive crises. Each time, the financial character combined with the political. The crisis that started in 2007 in the United States makes no exception and the effects on the metropolitan economy of Bucharest and implicitly, the IT sector, would be double. The results of the analysis show that the effects are significant but not dramatic. Two stages of evolution of the IT sector can be distinguished. The former is that of slow development based on the impulses accumulated during the economic boom. Paradoxically, the first year of the economic crisis, 2008, has been marked by the strongest growth of all economic indicators: 
number of new jobs, profit and turnover, irrespective of the size category. At the first sight, the crisis seemed not to in place yet and the economy would continue to prosper. The IT sector, strongly supported by governmental strategies, shows maturity and represents a growth engine of Bucharest economy.

The second stage is marked by a slow decline of the IT sector, much less dramatic than in other economic sectors at the national and regional level. The reduction of the employees number is accompanied by the decrease of FDI. Even under these circumstances, the IT sector is attractive for entrepreneurship. The number of new jobs created during the period of economic crisis is bigger showing an increasing significance of the sector for the overall economy. Challenged by the current crisis, the IT industry has successfully survived through reorganisations and adjustments. The reduction of the employees number is a matter of reorganisation and new investments indicate that in the last three years the IT sector has been attractive for business. The sector has undergone a diversification process in the same time.

The growing number of IT firms during the time of recession is the result of a strong local entrepreneurship. Supported by the location of MNCs in earlier years, the local entrepreneurship in IT firms is steadily growing. The highly skilled workforce is one of the sources for increasing entrepreneurship in IT firms. There are real chances that the potential entrepreneurship would evolve from a network of suppliers for MNCs to innovative and competitive companies at the European level. The tendency is not convergent yet, but there are some examples, such as RAV and more recently BitDefender, which indicate a strong capacity of adjustment, as long as they have survived the double crisis in Romania and even more than that they registered significant developments.

\section{Concluding remarks}

The paper aimed at the evaluation of the current crisis effects on IT sector in Bucharest based on two elements: the empirical analysis of the cluster emergence and consolidation and the descriptive analysis of IT firms. The identification of IT cluster in Bucharest reveals its national character. The correlation with the European and global context of IT industry development is a further objective of the study if statistics on interfirm relations would become accessible. The study helps identifying the potential cores of economic growth in Romania. The connection with scientific research at the international level is accomplished by using methodological tools that worked in similar studies. The paper contributes at highlighting the evolution of a postcommunist city at the fringe of the European Union during the economic crisis. In this way, the city is identified as one which needs to be deeper researched in order to be successfully addressed by regional development policies.

The late acknowledgement of the onset of the economic crisis by the Romanian government had limited but positive effects. The small firms have continued to develop encouraged by the political discourses and accumulated growth, even if the gig companies were much more aware of the on coming confrontation with the hardships of the crisis. Subsequently, the evolution of IT sector was positive at the beginning, in contrast with the general trend of decline that affected the majority of economic sectors. There is a slight decrease in the IT sector as well, but there is also a remarkable resilience of small firms to survive during the period of crisis. The IT industry keeps on growing thanks to combined actions of MNCs and entrepreneurship that make this industry one of the most attractive. Apparently, the success of the IT sector is dependent on the development of companies with high value added in the detriment of services firms. 
The attempt to evaluate the effects of the crisis on the IT sector is a way to emphasize not only the local but also the national character. In order to gain deeper insights the evolution should be subject of further research in the years to come. Another direction of research is the change of the geographical scale of analysis to the national level. In this way, the national perspective would identify the landmarks for future development strategies by regions and by sectors. Competitive sectors, successful regions and hotspots for intervention would channel the governmental actions for positive outcomes.

\section{References}

ANSELIN, L., VARGA, A., ACS, Z. (1997), Local Geographic Spillovers between University Research and High Technology Innovations, Journal of Urban Economics, 42, pp. 422-448.

CEES-JAN, P., HOOGERBRUGGE, M. (2011), Case Study on the Competitiveness of Bucharest Metropolitan Area, European Metropolitan Network Institute, Hague, 24 p.

CHAKRAVORTY, S., KOO, J., LALL, S.V. (2003), Metropolitan Industrial Clusters: Patterns and Processes, Policy Research Working Paper 3073, World Bank, 36 p.

CHILIAN, M., N. (2009), External Competitiveness of the Romanian Regions and Counties, Romanian Journal for Economic Forecasting, 11, 3, pp. 153-166.

DACHIN, A., POPA, R. (2011), Regional Disparities in Employment Structures and Productivity in Romania, Romanian Journal of Regional Science, 5, 2, pp. 65-75.

DAVELAAR, E.,J., NIJKAMP, P. (1989), Spatial Dispersion of Technological Innovation: A Case Study for the Netherlands by Means of Partial Least Squares, Journal of Regional Science, 29, 3, pp. 325-346.

DOSI, G. (1988), Sources, Procedures, and Microeconomic Effects of Innovation, Journal of Economic Literature. XXVI, pp. 1120-1171.

DOUSSARD, M., PECK, J., THEODORE, N. (2009), After Deindustrialisation: Uneven Growth and Economic Inequalitiy in "Postindustrial" Chicago, Economic Geography, 85, 2, pp. 183-207. Publisher.

FELDMAN, P., M. (1994), The Geography of Innovation, London, Kluwer Academic

FLORENCE, P., S. (1939), Report on the Location of Industry, UK: Political and Economic Planning, London,

FRENKEL, A. (2001), Why High Technology Firms Choose to Locate in or near Metropolitan Areas?, Urban Studies, 38, 7, pp. 1083-1101.

ISAIC-MANIU, I. (2008), Territorial Discrepancies concerning SMEs performances in Romania, Romanian Journal of Regional Science, 2, 1, pp. 108-26.

HOFE, R. V., CHEN, K. (2006), Whither or not industrial cluster: conclusions or confusions?, The industrial geographer 4, 1, pp. 2-28.

KARLSSON, C., MELLANDER, C., PAULSSON, T. (2003), A spatial ICT clusters in Sweden--an empirical method to identify necessary conditions for existence, Jönköping International Business School Jönköping University, Jönköping, Sweden, ERSA Congress CD ROM.

KOK, W. (2004), Facing the Challenge: The Lisbon Strategy for Growth and Employment, High Level Group, Office for Official Publications of the European Communities, Luxembourg. [retreived from: http://ec.europa.eu/research/evaluations/pdf/archive/fp6-evidence -base/evaluation_studies_and_-reports/evaluation_studies_and_reports_2004/ the_lisbon_strategy_for_growth_and_employment_report_from_the_high_level_group.pdf].

MALECKI, E. J. (1981), Technology and Regional Economic Development: Review and Prospects, Research Policy, 10, 4, pp.312-334.

MARKUSEN, A., HALL, P. AND GLASMEIER, A. (1986), High Tech America: The 
What, How, Where and Why of Sunrise Industries, London: Allen \& Unwin.

ROMAN, M. (2010), Regional Efficiency of the Knowledge Economy in the New EU

Countries: The Romanian and Bulgarian Case, Romanian Journal of Regional Science, 4, 1, pp. 33-53.

RONNAS, P. (1982), Centrally-planned urbanization: the case of Romania, Geografiska Annaler, Series B Human Geography, 64, 2, pp. 143-51, Blackwell Publishing.

SCOTT, A.,J. (1982), Locational patterns and Dynamics of Industrial Activity in the Modern Metropolis: a Review Essay, Urban Studies, 19, 2, pp.111-141.

STORPER, M. (1986), Technology and New Regional Growth Complexes: The Economics of Discontinuous Spatial Development, in: P. Nijkamp (ed), Technological Change, Employment and Spatial Dynamics, Berlin: Springer-Verlag, pp. 46-75.

WANG, C.,C., LIN, G. ,C., S. (2008), The growth and spatial distribution of China's ICT industry: new geography of clustering and innovation, Issues \& Studies 44, 145-192.

WOLFE, D., A., GERTLER, M., S. (2004), Clusters from the inside and out: local dynamics and global linkages, Urban Studies, 41, 5-6, 1071-1093.

* * * (2007), Competitiveness Report Romania, UniCredit Group.

* * * (2010), Centrul Român pentru Promovarea Comerțului şi Investițiilor Străine.

* * * (2008), Sector Overview: IT, Agenția Română pentru Investiții Străine.

* * * (2010), Potențialul competitiv al creşterii economice; linii directoare pentru o nouă politică industrială în România, Studii de Strategie şi Politici (SPOS), Institutul European din România.

Initial submission: 05.11.2011

Revised submission: 03.03.2012

Final acceptance: 31.05.2012

Correspondence: The Bucharest Academy of Economic Studies, 6, Piața Romană, Bucharest, Romania.

E-mail: cldpopescu@yahoo.com 
